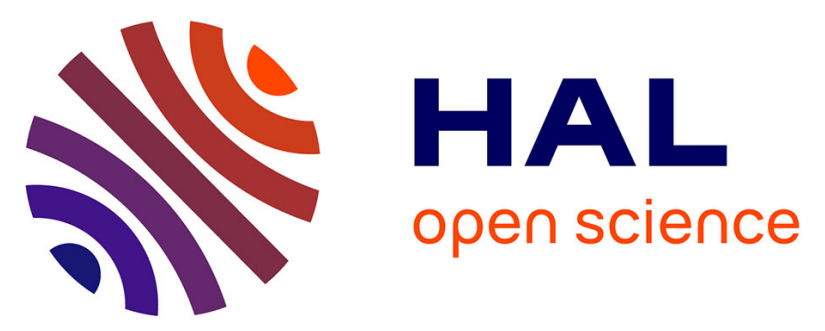

\title{
Design of a novel fuel cell-Fenton system: a smart approach to zero energy depollution
}

Le Huong Ti Xuan, Roseline Esmilaire, Martin Drobek, Mikhael Bechelany, Cyril Vallicari, Duy Linh Nguyen, Anne Julbe, Sophie Tingry, Marc Cretin

\section{- To cite this version:}

Le Huong Ti Xuan, Roseline Esmilaire, Martin Drobek, Mikhael Bechelany, Cyril Vallicari, et al.. Design of a novel fuel cell-Fenton system: a smart approach to zero energy depollution. Journal of Materials Chemistry A, 2016, 10.1039/C6TA05443A . hal-01432709

\section{HAL Id: hal-01432709 \\ https://hal.science/hal-01432709}

Submitted on 12 Jan 2017

HAL is a multi-disciplinary open access archive for the deposit and dissemination of scientific research documents, whether they are published or not. The documents may come from teaching and research institutions in France or abroad, or from public or private research centers.
L'archive ouverte pluridisciplinaire HAL, est destinée au dépôt et à la diffusion de documents scientifiques de niveau recherche, publiés ou non, émanant des établissements d'enseignement et de recherche français ou étrangers, des laboratoires publics ou privés. 


\title{
Design of a novel fuel cell-Fenton system: a smart approach to zero energy depollution
}

\author{
Thi Xuan Huong Le, ${ }^{\text {ab }}$ Roseline Esmilaire, ${ }^{a}$ Martin Drobek, ${ }^{a}$ Mikhael Bechelany, ${ }^{a}$ \\ Cyril Vallicari, ${ }^{a}$ Duy Linh Nguyen, ${ }^{a}$ Anne Julbe, ${ }^{a}$ Sophie Tingry ${ }^{a}$ and Marc Cretin ${ }^{a}$
}

A model azo dye pollutant, Acid Orange 7 (AO7), was removed efficiently from an aqueous medium by a smart eco-friendly Fuel Cell-Fenton (FC-Fenton) system without any external power supply. In this approach, AO7 was degraded by an electro-Fenton process at a designed cathode (Carbon Felt (CF)/porous Carbon ( $\mathrm{pC}$ )) supplied by direct clean electrical energy from abiotic glucose oxidation at a CF/gold anode (CF(Au). The highly active cathode was fabricated by an attractive route combining Atomic Layer Deposition (ALD) of ZnO on commercial carbon felts (CFs) followed by subsequent solvothermal conversion of the metal oxide to a metal organic framework (here ZIF-8). The asprepared composite material was further calcined at high temperature under a controlled atmosphere. A pC-based support with high specific surface area and nitrogen as a dopant was thus obtained, enhancing both conductivity and electrocatalytic properties toward $\mathrm{H}_{2} \mathrm{O}_{2}$ production from oxygen reduction. Degradation kinetics of AO7 $(0.1 \mathrm{mM}$ initial concentration) at the CFapC cathode was monitored by UV-vis spectrophotometry and High-Performance Liquid Chromatography (HPLC) to prove the efficiency of the composite material for the degradation of such a bio-refractory model molecule. Benefitting from the $\mathrm{H}_{2} \mathrm{O}_{2}$ production rate $\left(9.2 \mathrm{mg} \mathrm{L}^{-1} \mathrm{~h}^{-1}\right)$ by the pC layer, $\mathrm{AO} 7(35.0 \mathrm{mg}$ $\left.\mathrm{L}^{-1}\right)$ was degraded by the electro-Fenton process in acidic medium $(\mathrm{pH}=3)$ with removal efficiency reaching $90 \%$ in $10 \mathrm{~h}$. The durability of the system was extended for more than 2 months with an average power output of $170 \mathrm{~mW} \mathrm{~m}{ }^{-2}$, confirming this abiotic FC-Fenton system as a promising, green, future technology for both environmental and energy-related areas, including membrane-coupled reactor systems.

\section{Introduction}

The scarcity of pure water worldwide is dramatically affecting the economic development of Third-World countries, but also the industrial growth as a whole. When considering water recycling and reuse, new technologies such as Electrochemical Advanced Oxidation Processes (EAOP), currently deserve strong attention. Indeed, such processes are of high interest since they are very efficient for the degradation of refractory pollutants that cannot be eliminated by conventional techniques. Among EAOP, the electro-Fenton process (EF) allows for in situ generation of highly reactive and non-selective ${ }^{\circ} \mathrm{OH}$ radicals through oxygen reduction to hydrogen peroxide (eqn (1)) and its further reduction to ${ }^{\circ} \mathrm{OH}$ through the Fenton reaction (eqn (2)) in the presence of $\mathrm{Fe}^{2+}$, which induces the total mineralization of pollutants.

${ }^{a}$ Institut Européen des Membranes, IEM UMR-5635, Université de Montpellier, ENSCM, CNRS, Place Eugène Bataillon, 34095 Montpellier Cedex 5, France. E-mail: mikhael.bechelany@univ-montp2.fr; marc.cretin@umontpellier.fr

${ }^{b}$ Van Lang University, 45 Nguyen Khac Nhu, District 1, Ho Chi Minh City, Vietnam

$$
\begin{gathered}
\mathrm{O}_{2}+2 \mathrm{H}^{+}+2 \mathrm{e}^{-} \rightarrow \mathrm{H}_{2} \mathrm{O}_{2} \\
\mathrm{Fe}^{2+}+\mathrm{H}_{2} \mathrm{O}_{2}+\mathrm{H}^{+} \rightarrow \mathrm{Fe}^{3+}+\cdot \mathrm{OH}+\mathrm{H}_{2} \mathrm{O}
\end{gathered}
$$

In the EF process, the efficiency of pollutant degradation strongly depends on the cathode material where ${ }^{\circ} \mathrm{OH}$ radicals have to be generated. Carbon-based electrodes like vitreous carbon, ${ }^{1}$ carbon felt $(\mathrm{CF}),{ }^{2}$ and carbon sponge ${ }^{3}$ are commonly used as cathodes in oxygen-dissolved solutions to produce hydrogen peroxide, crucial species for the effective destruction of Persistent Organic Pollutants (POPs). The enhancement of cathode material performances for the electro-generation of $\mathrm{H}_{2} \mathrm{O}_{2}$ has, thus, received increasing interest through the development of composite electrodes prepared with polyacrylonitrile, ${ }^{4}$ ethanol/ hydrazine hydrate, ${ }^{5}$ nitrogen-functionalized carbon nanotubes, ${ }^{6}$ multi-walled carbon nanotubes/surfactants, ${ }^{7}$ polypyrrole/anthraquinonedisulphonate composite films, ${ }^{8}$ thermal treatments ${ }^{9}$ and graphene. ${ }^{10}$ Enhanced performance is mainly due to an increase of both the electronic conductivity of materials and the electrochemical active surface area in the developed microporous nanostructures.

In order to drive the electrons required for the oxygen reduction reaction (ORR), an electric generator is generally 
required. ${ }^{11,12}$ To overcome this issue, innovative solutions have been proposed. It was previously shown that microbial fuel cells can be used for wastewater treatment as a sustainable alternative energy source. ${ }^{13}$ The anode side contains an electroactive biofilm working as a biocatalyst to produce electrons while the EF process takes place at the cathode. The biocatalyst has been grown on graphite rods, ${ }^{13}$ porous graphite felt, ${ }^{\mathbf{1 4}}$ granular graphite, ${ }^{15} \mathrm{CF}$ brush ${ }^{\mathbf{1 6}}$ or $\mathrm{CF} .{ }^{17}$ In spite of their very promising performance for both energy savings and wastewater treatment, these processes still suffer from some restrictions associated to complex experimental conditions, limited bacteria durability and low electrocatalytic electrode properties.

An attractive alternative to microbial fuel cell-driven EF processes is the direct production of electrons through the glucose oxidation process. Glucose fuel cells can be classified into three types according to the nature of the catalyst: (i) enzymatic catalyst, ${ }^{18}$ (ii) microbial catalyst ${ }^{19}$ and (iii) metal catalyst. $^{20}$ The electro-oxidation of non-enzymatic glucose with metallic nanoparticles displays long-term stability and can be performed on electrode materials containing $\mathrm{Ni},{ }^{21} \mathrm{Pt},{ }^{22} \mathrm{Pd}-\mathrm{Rh},{ }^{23}$ $\mathrm{Pt}-\mathrm{Ru},{ }^{24} \mathrm{Au}^{24}$ or $\mathrm{Au}-\mathrm{Pt}-\mathrm{Pd} .^{25}$

In order to move towards a clean electrical energy system, we propose, in this study, a smart system whose working principle is based on abiotic glucose oxidation to drive the EF process. We focused our work on the development of relevant electrodes with electrocatalytic properties resulting from modifications of commercial CFs. In order for the system to operate efficiently, the electric potential difference between the two electrodes must be large enough and the redox reactions must be sufficiently fast at the electrodes to limit kinetic losses. At the anode, the glucose oxidation reaction was performed on gold particles deposited onto commercial CFs (CF@Au); whereas at the cathode, a novel porous carbon-based material (CF@pC) was prepared with relevant catalytic properties to facilitate $\mathrm{H}_{2} \mathrm{O}_{2}$ production, to extend the system durability and to ensure an easy and fast procedure, unlike microbial fuel cell-Fenton systems.

According to our best knowledge, such a concept of an abiotic fuel cell-Fenton (FC-Fenton) system has never been described in the literature and its application for efficient pollutant degradation represents an innovative green technology approach for both environmental and energy-related areas.

\section{Experimental}

\subsection{Materials}

The carbon felt was purchased from A Johnson Matthey Co., Germany. Diethyl zinc (DEZ), $\mathrm{Zn}\left(\mathrm{CH}_{2} \mathrm{CH}_{3}\right)_{2}$ (95\%), 2-methyl imidazole (2-mim, 97\% purity), chloroauric acid trihydrate $\left(\mathrm{HAuCl}_{4} \cdot 3 \mathrm{H}_{2} \mathrm{O}, 99.99 \%\right)$, Acid Orange II sodium salt (AO7), D-(+)-glucose monohydrate, sodium sulfate (anhydrous, 99.0$100.5 \%)$, iron(II) sulfate heptahydrate (99\%), methanol (99.8\%) and sulfuric acid (98\%) were bought from Sigma-Aldrich; potassium hexacyanoferrate $(\geq 99 \%)$ and potassium nitrate $(\geq 99 \%$ ) from Fluka; potassium hydroxide ( $\mathrm{KOH}$ pellets pure) from Merck and all chemicals were used without further purification.

\subsection{The fuel cell-Fenton system}

The FC-Fenton system was composed of two cylindrical compartments separated by a Nafion ${ }^{\circledR} 117$ perfluorinated membrane $(3.5 \mathrm{~cm} \times 5 \mathrm{~cm})$, as depicted in Fig. 1 . The anode electrode consisted of CF@Au while the cathodic electrode consisted of porous carbon deposited onto commercial $\mathrm{CF}$ (CF@pC). The anode compartment contained $90 \mathrm{~mL}$ of glucose $(0.5 \mathrm{M})$ in $0.1 \mathrm{M} \mathrm{KOH}(\mathrm{pH} 11.0)$ saturated by $\mathrm{N}_{2}$ under magnetic stirring; whereas the cathode compartment contained $90 \mathrm{~mL}$ aqueous solution of $\mathrm{AO} 7(0.1 \mathrm{mM})$ with $\mathrm{FeSO}_{4} \cdot 7 \mathrm{H}_{2} \mathrm{O}(0.2 \mathrm{mM})$ as the catalyst and $\mathrm{Na}_{2} \mathrm{SO}_{4}(50 \mathrm{mM})$ as a supporting electrolyte adjusted at $\mathrm{pH}=3$ and saturated by oxygen. The $\mathrm{pH}$ of each compartment was maintained by adding either $\mathrm{H}_{2} \mathrm{SO}_{4}(1 \mathrm{M})$ or $\mathrm{KOH}(1 \mathrm{M})$. The decomposition of $\mathrm{AO} 7$ was monitored by measuring the dye absorbance at the selected single wavelength of $485 \mathrm{~nm}$, specific for azo bonds, ${ }^{25}$ with a Jenway 6300 spectrophotometer (Barioworld Scientific Ltd, Dunmow, UK). Concentrations of $\mathrm{AO} 7$ during the experiments were measured in parallel by an HPLC system (Waters 717 autosampler and Waters 616 Pump) with a photodiode array detector (Waters 2996 photodiode array detector) fitted with a reverse phase (RP) Thermo Scientific C18 column $(L=250 \mathrm{~mm}$, I.D. $=4.6 \mathrm{~mm}$, and $5 \mu \mathrm{m}$ particles).

The electrochemical performance of the FC-Fenton system was evaluated by connecting the abiotic anode and the electroFenton cathode under a discharge resistor of 5 ohms. The evolution of the potential of each electrode was measured independently by introducing a reference electrode $(\mathrm{Ag} / \mathrm{AgCl})$ in each compartment. The delivered current density and the output power density were derived from the resistance and the cell voltage $(U)$, with $P\left(\mathrm{~mW} \mathrm{~m}^{-2}\right)=U(\mathrm{mV}) \times j\left(\mathrm{~mA} \mathrm{~m}^{-2}\right)$.

2.2.1. Fabrication of the CF@Au anode. The anode was firstly fabricated by electro-deposition of a gold layer onto the surface of a commercial carbon felt (raw CF, Johnson Matthey Co., Germany) $(4.0 \mathrm{~cm}$ length $\times 1.0 \mathrm{~cm}$ width $\times 1.0 \mathrm{~cm}$

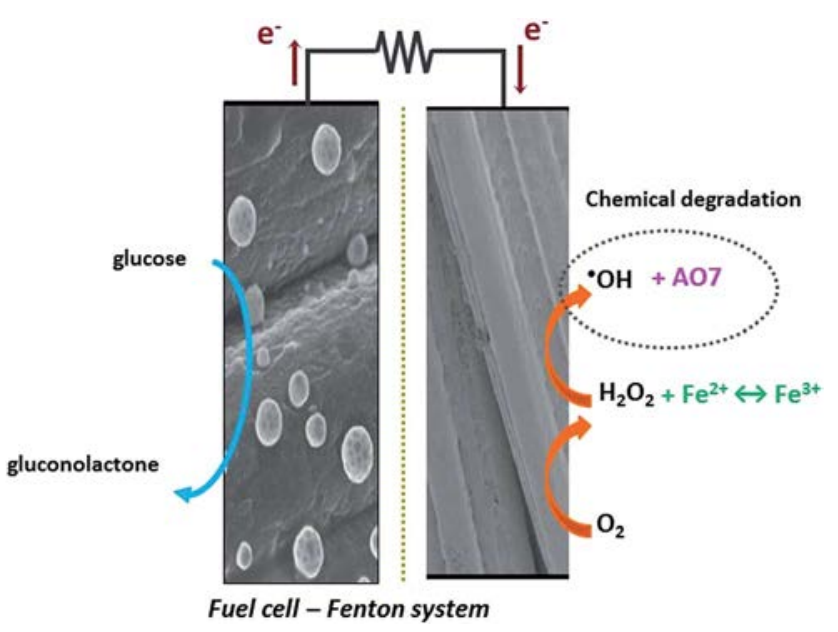

Fig. 1 Schematic of the FC-Fenton system. 
thickness). Electrodeposition was performed using cyclic voltammetry (CV) by running 70 scans from -0.9 to $0 \mathrm{~V}$ versus SCE at a scan rate of $10 \mathrm{mV} \mathrm{s}^{-1}$ in a $\mathrm{N}_{2}$ saturated solution containing $0.05 \mathrm{mg} \mathrm{mL} \mathrm{m}^{-1}$ chloroauric acid. The process was recorded on a $\mu 3$ AUT70466 Autolab system (Eco Chemie BV, Netherlands) at a scan rate of $10 \mathrm{mV} \mathrm{s}^{-1}$ using a three-electrode system with the CFs as the working electrode, a saturated calomel electrode (SCE) as the reference electrode and platinum foil as the counter electrode. In order to form the gold particles by dewetting, as described in our previous work, ${ }^{26}$ an additional thermal treatment was required. It was performed in a tubular furnace (Vecstar Ltd) under flowing nitrogen $\left(200 \mathrm{~mL} \mathrm{~min}^{-1}\right.$ ) with a heating rate of $5{ }^{\circ} \mathrm{C} \min ^{-1}$ up to a temperature of $1000{ }^{\circ} \mathrm{C}$.

2.2.2. Fabrication of the CF@pC cathode. Cathodes have been prepared by an original strategy combining 3 steps: (i) atomic layer deposition (ALD) of a metal oxide (MO), (ii) solvothermal conversion of MO to a metal organic framework (MOF) and finally (iii) MOF carbonization, forming pC with a high specific surface area.

(i) A home-made ALD setup ${ }^{27,28}$ was used for depositing $\mathrm{ZnO}$ thin layers onto commercial CF $(4.0 \mathrm{~cm}$ length $\times 1.0 \mathrm{~cm}$ width $\times 1.0 \mathrm{~cm}$ thickness) at $100^{\circ} \mathrm{C}$ using sequential exposures of DEZ and deionized water separated by a purge with dry argon (Ar flow rate of $100 \mathrm{sccm}$ ). The deposition protocol was as follows: (a) $0.5 \mathrm{~s}$ pulse of DEZ, $30 \mathrm{~s}$ exposure and $50 \mathrm{~s}$ purge with dry Ar; (b) $2 \mathrm{~s}$ pulse of $\mathrm{H}_{2} \mathrm{O}, 40 \mathrm{~s}$ of exposure and $60 \mathrm{~s}$ purge with dry Ar. The selected pulse, exposure and purge times were chosen both to ensure completion of the ALD surface reactions and to prevent any mixing of the reactive species. The characteristics of the ZnO ALD deposits (thickness, crystalline phase and grain/ crystallite sizes) were found to be insensitive to both support morphology and composition. The growth rate per cycle of the zinc oxide layers was controlled by measuring the films thickness deposited on Si-wafer companion substrates placed in the $A L D$ reaction chamber.

(ii) The ZnO-coated CFs were submitted to a solvothermal treatment in a closed pressure vessel (Teflon-lined stainlesssteel $45 \mathrm{~mL}$ autoclave) containing a solution of 2-mim in methanol (10 wt\% 2-mim). The autoclave was heated at $100{ }^{\circ} \mathrm{C}$ for $5 \mathrm{~h}$ in a conventional oven. After this solvothermal treatment, the resulting material was washed five times with methanol and dried for $2 \mathrm{~h}$ at $70^{\circ} \mathrm{C}$.

(iii) The as-modified CFs were further carbonized at $1000^{\circ} \mathrm{C}$ for $10 \mathrm{~h}$ under nitrogen in order to obtain a pC layer deposited onto the commercial CFs. The resulting CF@pC cathode was expected to offer a high specific surface area, enhanced conductivity and enhanced electrocatalytic properties toward $\mathrm{H}_{2} \mathrm{O}_{2}$ production from oxygen reduction.

\subsection{Material characterization}

Chemical and structural characterizations of the prepared materials were performed by scanning electron microscopy (SEM, Hitachi S-4800), X-ray diffraction (XRD) (PANAlytical Xpert-PRO diffractometer equipped with a X'celerator detector using Ni-filtered Cu-radiation), EDX analysis (Silicon Drift Detector (SDD), X-MaxN, Oxford Instrument) coupled to a Zeiss EVO HD15 SEM analyzer. X-ray photoelectron spectroscopy (XPS) measurements were conducted using an ESCALAB 250 Thermal Electron with AlK $\alpha(1486.6 \mathrm{eV})$. Binding energies were calibrated using the contained carbon $(\mathrm{C} 1 \mathrm{~s}=$ $284.4 \mathrm{eV})$.

\subsection{Electrocatalytic activity measurements}

Electrochemical analysis was performed with a $\mu 3$ AUT70466 Autolab system (Eco Chemie BV, Netherlands) with a conventional three-electrode assembly composed of a SCE reference, a Pt foil counter electrode and the developed electrodes as working electrode. $\mathrm{CV}$ was performed in $1.0 \mathrm{M} \mathrm{KNO}_{3}$ containing the redox probe $\mathrm{Fe}(\mathrm{CN})_{6}{ }^{3 / 4} 10 \mathrm{~mm}$. The electroactive surface area of the cathodes was evaluated according to the RandlesSevcik relation. ${ }^{29,30}$

To evaluate the catalytic activity of the CF@pC cathode towards $\mathrm{H}_{2} \mathrm{O}_{2}$ electro-generation, linear sweep voltammetry (LSV) measurements were performed in $45 \mathrm{~mL} \mathrm{Na}_{2} \mathrm{SO}_{4}(50 \mathrm{mM})$ solution at $\mathrm{pH}=3.0$. Before the measurements, the solution was saturated by oxygen for $10 \mathrm{~min}$ and the potential was scanned from the open circuit potential to $-1.2 \mathrm{~V}$ versus $\mathrm{Ag} / \mathrm{AgCl}$ at $5 \mathrm{mV} \mathrm{s}^{-1}$ in the three-electrode system. The electro-generation of $\mathrm{H}_{2} \mathrm{O}_{2}$ was carried out at the potential of $-0.21 \mathrm{~V} v s$. $\mathrm{Ag} / \mathrm{AgCl}$ by chronopotentiometry, and the resulting $\mathrm{H}_{2} \mathrm{O}_{2}$ concentrations were determined by spectrophotometry using potassium titanium(Iv) oxalate as a colored indicator. The absorbance of the yellow pertitanic acid complex between $\mathrm{H}_{2} \mathrm{O}_{2}$ and potassium titanium oxalate in acidic solution was measured by a Jenway 6300 spectrophotometer (Barioworld Scientific Ltd, Dunmow, UK) at $\lambda=$ $400 \mathrm{~nm}$ through a $1 \mathrm{~cm}$ polystyrene cuvette. The calibration curve was obtained from standard $\mathrm{a}_{2} \mathrm{O}_{2}$ solution that was titrated against potassium permanganate solution $(0.1 \mathrm{~N})$.

To evaluate the catalytic activity of the CF@Au anode towards glucose electro-oxidation, $\mathrm{CV}$ measurements were performed at $50 \mathrm{mV} \mathrm{s}^{-1}$ in $0.1 \mathrm{M} \mathrm{KOH}$ solution containing $10 \mathrm{mM}$ glucose. The glucose solution was stirred for $24 \mathrm{~h}$ before testing. The glucose oxidation potential was fixed from the LSV in $0.1 \mathrm{M}$ $\mathrm{KOH}$ solution containing $0.5 \mathrm{M}$ glucose.

\section{Results and discussion}

To develop an efficient FC-Fenton system, the innovation proposed in this work involves relevant modifications of commercial CFs according to two different strategies: (i) preparation of a cathode from the modification of CFs with a pC layer and (ii) preparation of an anode by electrodeposition of gold particles onto CFs. The key parameters of both steps were examined through a description of the deposits (location, quantity and physico-chemical characteristics) and investigation of the electro-catalytic activity of the as-prepared materials assembled in a FC-Fenton cell. The electrodes were assembled in a FC-Fenton cell whose characteristics were described and discussed in relation with the electrode structure and morphology, and with the degradation kinetics of the pollutant AO7 in an aqueous solution. 


\subsection{Characterization of both the CF@Au anode and CF@pC} cathode

In the CF@Au material, the as-deposited gold particles play the catalyst role for the direct electro-oxidation of glucose in the FC-Fenton system. The gold particles, with an average size of $300 \mathrm{~nm}$ calculated by the ImageJ software, are uniformly distributed onto the CFs, as evidenced on the SEM images at different magnifications (Fig. 2d compared to raw CFs in 2a) and EDX mapping results (Fig. S1 $\dagger$ ). The XRD analysis of the asprepared electrode (Fig. 2e) features both a broad diffraction peak around $2 \theta=23^{\circ}$, corresponding to a hexagonal graphite structure (002), and a less intense peak at $43^{\circ}$. Crystalline gold particles on the surface of CF were proved through the emergence of sharp peaks at $38.2^{\circ}(111), 44.2^{\circ}$ (200) and $64.6^{\circ}(220)$, which are specific for the cubic phase of gold..$^{31,32}$ Gold particles were thus successfully obtained by reduction of the chloroauric anions by electrodeposition of gold layers onto the CF surface subsequently transformed into particles by thermal treatment. The catalytic activity of the CF@Au electrode was tested by running CVs in $0.1 \mathrm{M} \mathrm{KOH}$ solution in either the presence or absence of glucose (10 mM). In the absence of glucose (Fig. 2f), the CV of the CF@Au electrode shows two peaks relative to gold surface-oxides formation and reduction, respectively, in alkaline media. ${ }^{33,34}$ In the presence of glucose, raw CFs are inactive for glucose electro-oxidation in the investigated potential range; whereas the CF@Au electrode shows the typical voltammetric behavior characterized by three electrochemical processes: (1) formation of an adsorbed glucose layer on the gold electrode
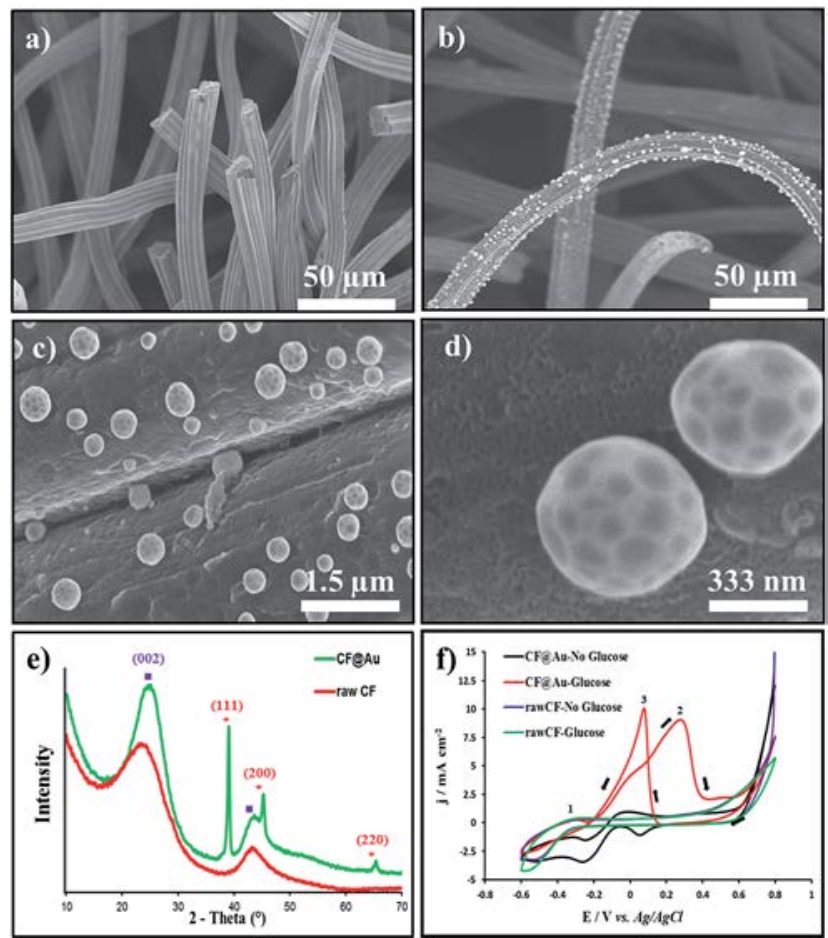

Fig. 2 SEM images of raw CF (a) and CF@Au anode (b-d) at different magnifications, $\mathrm{X}$-ray diffraction patterns of raw $\mathrm{CF}$ and $\mathrm{CF}\left(\mathrm{Au}, \mathrm{Au}\left({ }^{*}\right)\right.$, $\mathrm{C}(\boldsymbol{\square})(\mathrm{e}) . \mathrm{CV}$ s in $10 \mathrm{mM}$ glucose in $0.1 \mathrm{M} \mathrm{KOH}$ of raw $\mathrm{CF}$ and $\mathrm{CF}$ (aAu anode in the presence or absence of $10 \mathrm{mM}$ glucose at $50 \mathrm{mV} \mathrm{s}^{-1}$ (f). surface through dehydrogenation of the anomeric carbon in the glucose molecules, ${ }^{35,36}$ (2) oxidation of the as-adsorbed glucose forming the gluconolactone species (appearance of a large left shoulder peak around $0.3 \mathrm{~V}$ ) and (3) re-adsorption and oxidation of another glucose. ${ }^{37}$

The active cathode was fabricated by combining ALD of metal oxide ( $\mathrm{ZnO}$ ) on CFs followed by its solvothermal conversion to ZIF-8, and a subsequent calcination under a controlled atmosphere to forming $\mathrm{pC}$-based deposits. The presence of $\mathrm{ZnO}$ is highlighted by the diffraction peaks at $2 \theta=31.7^{\circ}, 34.4^{\circ}$ and $36.2^{\circ}$, corresponding to the diffraction lines (100), (002) and (101) of the wurtzite hexagonal ZnO phase. After 250 ALD cycles, the thickness of the $\mathrm{ZnO}$ layer was $\sim 50 \mathrm{~nm}$ and the mean size of crystallites in the $\mathrm{ZnO}$ layer was $18 \mathrm{~nm}$, as calculated using the Debye-Scherrer equation reported elsewhere. ${ }^{38}$ The solvothermal conversion of the as-modified CFs resulted in a ZIF-8based composite material with ZIF- 8 crystals (0.1-1 $\mu \mathrm{m}$ in size) homogeneously covering the CFs (Fig. 3a). Both ZIF-8 and ZnO were found to co-exist on the CFs, as confirmed in Fig. 3e by the characteristic XRD peaks of both ZIF-8 $\left(2 \theta=7.3^{\circ}(011), 10.4^{\circ}\right.$
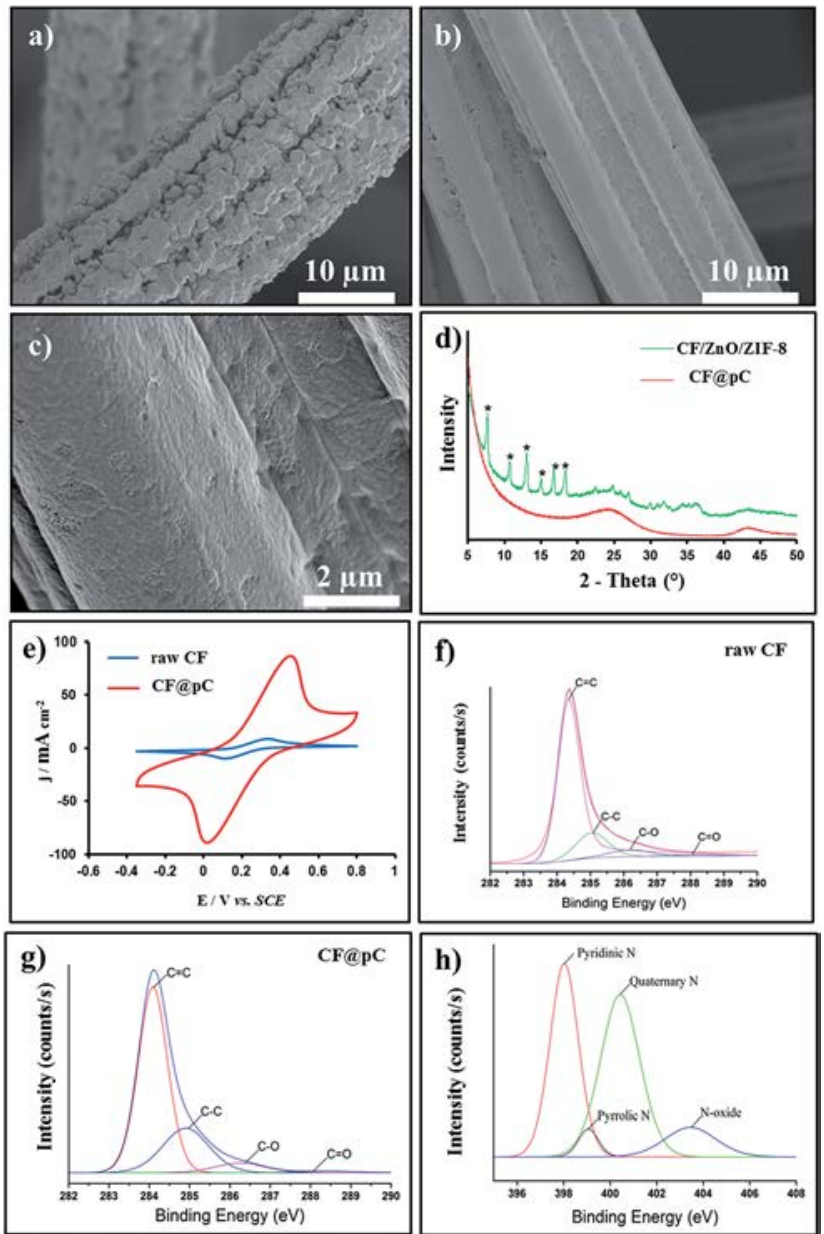

Fig. 3 SEM images of CF/ZnO/ZIF-8 (a) and CFapC samples (b and c); XRD patterns of both CF/ZnO/ZIF-8 and CF@pC samples, ZIF-8 (*) (d); CVs of raw CF and CFapC electrodes (e) in potassium hexacyanoferrate solution $(10 \mathrm{mM})$ at a scan rate of $7 \mathrm{mV} \mathrm{s}^{-1}$; C1s spectrum of raw CF (f) and CF@pC (g) and N1s spectrum of CFapC (h). 
(200), $\left.12.7^{\circ}(112), 18.0^{\circ}(222)\right)$ and $\mathrm{ZnO}\left(2 \theta=31.7^{\circ}(100), 34.4^{\circ}\right.$ (002), $\left.36.2^{\circ}(101)\right)$. Hence, under the selected reaction conditions, the synthesis resulted in $\mathrm{CF} / \mathrm{ZnO} / \mathrm{ZIF}-8$ composites in which a thin $\mathrm{ZnO}$ nanolayer was locally dissolved by the 2-mim linker and directly converted to ZIF-8 with a yield $>60 \%$. The above composite was further carbonized under a controlled atmosphere, leading to the formation of thin $\mathrm{pC}$ layers homogeneously covering the surface of the CFs (Fig. $3 \mathrm{~b}$ and c). XRD analysis (Fig. 3d) confirmed the full carbonization of both ZIF-8 and $\mathrm{ZnO}$ in the CF@pC material after thermal treatment. The EDX mapping (Fig. S7 $\dagger$ ) clearly shows the presence of $\mathrm{C}$ and $\mathrm{O}$ atoms ( $\sim 96$ and $\sim 4$ at\%, respectively), which corresponds to the $\mathrm{pC}$ on the surface, and tends to be partially oxidized, as pointed out by XPS analysis. In Fig. $3 \mathrm{f}$ and $\mathrm{g}$, the presence of $\mathrm{C}=\mathrm{C}$ and $\mathrm{C}-\mathrm{C}$ carbonaceous structures are evidenced by the binding energies of $284.3 \mathrm{eV}$ and $285 \mathrm{eV}$, respectively. The oxygen contamination in both materials is attested by the presence of carbon-oxygen bonds $(\mathrm{C}-\mathrm{O}(286.79 \mathrm{eV})$ and $\mathrm{C}=\mathrm{O}(287.81 \mathrm{eV}))$. The presence of carbonaceous structures and the absence of $\mathrm{ZnO}$ in the resulting $\mathrm{CF} @$ pC material confirm that a metal-free carbon material was successfully synthesized. Besides, the elemental analysis of CF@pC by XPS indicated this as well as the presence of nitrogen $(1.73 \%)$ on the porous carbon that could be attributed to N-containing functional groups like pyridinic-N $(398.2 \mathrm{eV})$, pyrrolic-N $(399.8 \mathrm{eV})$, quaternary-N $(400.8 \mathrm{eV})$ and N-oxide (403 eV) (Fig. $3 \mathrm{~h}$ ), as reported elsewhere. ${ }^{39,40}$ These N-containing groups improve the hydrophilic characteristics that promote both electron transport and mass transfer, and thus, electrochemical performance toward ORR during the EF process. ${ }^{41,42}$

According to $\mathrm{N}_{2}$ physisorption measurements, it is apparent that the carbon layer on the CFs generates a porous structure consisting mainly of micropores (pore volume $=0.082 \mathrm{~cm}^{2} \mathrm{~g}^{-1}$ ) increasing the specific surface area of the $\mathrm{CF}$ material from $0.0915 \mathrm{~m}^{2} \mathrm{~g}^{-1}$ to $64 \mathrm{~m}^{2} \mathrm{~g}^{-1}$. As previously mentioned, ${ }^{43,44}$ the microstructure of such a cathode material can facilitate the diffusion and transformation of oxygen to $\mathrm{H}_{2} \mathrm{O}_{2}$ on the surface, and thus, the $\mathrm{CF} @ \mathrm{pC}$ material was explored for the in situ electrochemical production of $\mathrm{H}_{2} \mathrm{O}_{2}$.

The benefit of the pC structure on the electroactive surface area is also obvious from the increase in the electrochemical redox signal of the redox probe $\left[\mathrm{Fe}(\mathrm{CN})_{6}\right]^{3-} /\left[\mathrm{Fe}(\mathrm{CN})_{6}\right]^{4-}$ in solution at the $\mathrm{CF} @$ pC electrodes (Fig. 3e). Compared to raw $\mathrm{CF}$, the CF@pC electrode exhibits an estimated electroactive surface area that is 9.3 times higher (calculated by Randles-Sevcik formula ${ }^{29,30}$. This result may be attributed to an enhanced specific surface area, a high degree of graphitization and the presence of abundant graphitic nitrogen atoms. ${ }^{45}$ Fig. 4a shows the LSV of $\mathrm{H}_{2} \mathrm{O}_{2}$ production by running the potential of the $\mathrm{CF} @ \mathrm{pC}$ and raw $\mathrm{CF}$ electrodes from the open circuit potential to $-1.2 \mathrm{~V} v$ s. $\mathrm{Ag} / \mathrm{AgCl}$. The production of $\mathrm{H}_{2} \mathrm{O}_{2}$ starts at $+0.2 \mathrm{~V}$ on the $\mathrm{CF} @$ pC electrode, whereas it starts at $-0.3 \mathrm{~V}$ on the raw $\mathrm{CF}$ electrode with high overvoltage. This observation, and the higher current densities delivered by the CF@pC electrode, points to the faster electron transfer kinetics for ORR on the modified cathode..$^{41}$ The electrocatalytic ability of CF@pC electrodes for $\mathrm{O}_{2}$ reduction was investigated by measuring the $\mathrm{H}_{2} \mathrm{O}_{2}$

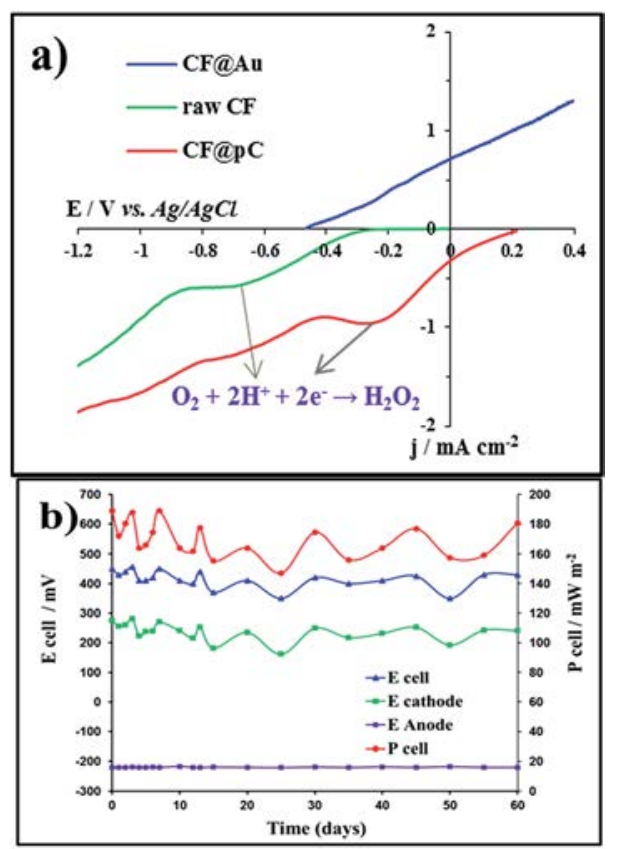

Fig. 4 (a) LSV of raw CF and CFapC cathodes obtained in $50 \mathrm{mM}$ $\mathrm{Na}_{2} \mathrm{SO}_{4}, \mathrm{O}_{2}$ saturated solution, $\mathrm{pH}=3$. Scan rate $5 \mathrm{mV} \mathrm{s}^{-1}$; and CF@Au anode in $0.1 \mathrm{M} \mathrm{KOH}$ solution with $0.5 \mathrm{M}$ glucose $(\mathrm{pH}=11.0)$. (b) Electrical performance of the $\mathrm{FC}$-Fenton cell at $30^{\circ} \mathrm{C}$ with the $\mathrm{CF} / \mathrm{pC}$ cathode in $\mathrm{O}_{2}$-saturated solution $\left(0.1 \mathrm{mM}\right.$ of $\mathrm{AO}$, $50 \mathrm{mM} \mathrm{Na} \mathrm{SO}_{4}$, $0.20 \mathrm{mM} \mathrm{Fe}{ }^{2+}, \mathrm{pH}=3.0$ ) and the CFaAu anode in $0.1 \mathrm{M} \mathrm{KOH}(\mathrm{pH}=$ 11.0) containing $0.5 \mathrm{M}$ glucose.

production at a constant potential of $-0.21 \mathrm{~V} v s$. Ag/AgCl. After $60 \mathrm{~min}$, a stable concentration of $\mathrm{H}_{2} \mathrm{O}_{2}\left(9.2 \mathrm{mg} \mathrm{L}^{-1}\right)$ was obtained at $\mathrm{pH}=3$ whereas no $\mathrm{H}_{2} \mathrm{O}_{2}$ generation was detected at the raw $\mathrm{CF}$ electrodes, revealing the outstanding performance of the newly designed CF@pC cathode.

Besides, as observed in Fig. 4a, glucose oxidation at CF@Au anode starts at $-0.46 \mathrm{~V} v s$. $\mathrm{Ag} / \mathrm{AgCl}$. For efficient operation, it is thus obvious that the raw $\mathrm{CF}$ cathode cannot be combined with the CF@Au anode to build a FC-Fenton system due to the low electric potential difference between the two electrodes. However, the $\mathrm{CF} @ \mathrm{pC}$ electrode has great promise as an efficient cathode to generate $\mathrm{H}_{2} \mathrm{O}_{2}$ at a low potential in an electro-Fenton process for pollutants degradation.

\subsection{FC-Fenton system efficiency}

The FC-Fenton system was operated by connecting both the abiotic CF@Au anode and the CF@pC cathode in a two-chambers cell separated by a Nafion membrane. Fig. 4 presents the operation feature of the FC-Fenton system where direct clean electrical energy from abiotic glucose oxidation at the CF@Au electrode in an anodic compartment is transferred to the cathodic one for oxygen reduction at the CF@pC electrode. To avoid the limitation that could be induced by glucose consumption, a high glucose concentration $(0.5 \mathrm{M})$ was used in the anodic compartment of the system. An average output current density of $360.3 \pm 51.5 \mathrm{~mA} \mathrm{~m}^{-2}$ at $400 \pm 50 \mathrm{mV}$ was generated, providing electrons for the ORR at the cathode where 
the hydroxyl radicals $\left({ }^{\circ} \mathrm{OH}\right)$ were formed. Fig. $4 \mathrm{~b}$ clearly demonstrates that an average power output of $170 \mathrm{~mW} \mathrm{~m}^{-2}$ was continuously produced for at least two months. The CF@Au electrode exhibits stable electroactivity toward glucose oxidation at around $-220 \mathrm{mV}$ due to the presence of the gold nanoparticles. In the cathodic compartment, regular potential oscillation takes place due to both proton consumption in ORR (eqn (1)) and exchange through the Nafion membrane, leading to $\mathrm{pH}$ variations affecting the cathodic potential values. As a result, pH adjustment plays a key role in maintaining a stable performance of the FC-Fenton system. The characterization of both the CF@Au anode and the CF@pC cathode before/after two months use in the FC-Fenton system has been performed by SEM (Fig. S4 and S8 $\dagger$ ), EDX mapping (Fig. S1 and S7 $\dagger$ ), XPS analysis (Fig. S2, S5 and S9†), EDX analysis (Fig. S3, S6 and S10†) and elemental composition measurements (Tables S1-S4†) in order to prove the durability of both fabricated electrodes. As observed from Fig. $\mathrm{S} 4, \dagger$ the gold particles were still steadily deposited on the CF@Au anode after two months use in the FCFenton system. In the case of the CF@pC cathode, some additional impurities (F, Si, S) at very low quantities (Table S4†) occurred after two months of system operation. This contamination comes from the dye solution continuously supplied into the cathodic compartment. However, no negative impact on the FC-Fenton efficiency was observed. These results clearly confirm the robustness of both cathode and anode electrodes, attesting to their long-term stability in the proposed fuel cell system.

The AO7 degradation was followed by HPLC analysis during electrolysis. As shown in Fig. 5b, the concentration of AO7 decreases rapidly at the early stage of electrolysis with approximately $70 \%$ conversion within 3 hours. Subsequently, degradation decelerates because the decomposition of $\mathrm{AO} 7$ by the EF process leads to the formation of various aromatic compounds

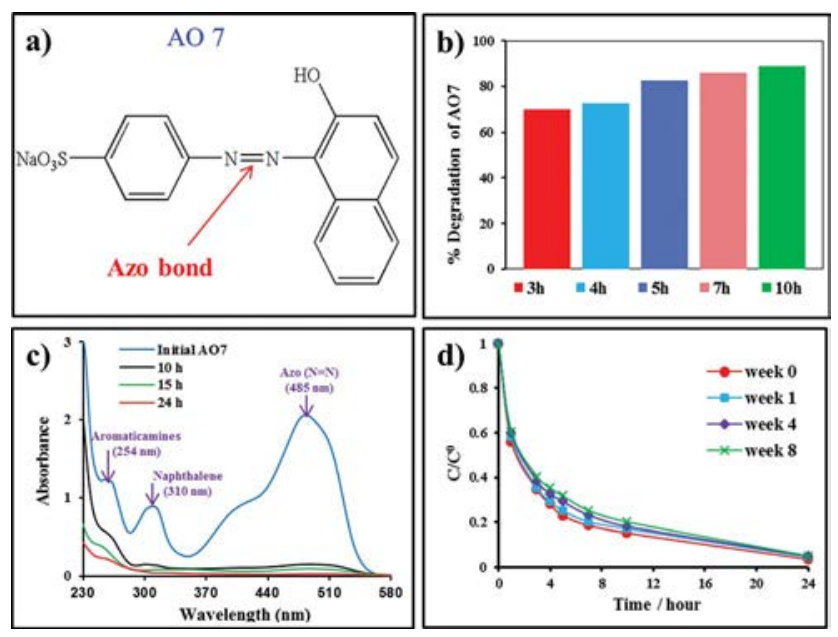

Fig. 5 (a) Molecular structure of AO7. (b) Percent removal of AO7 by the FC-Fenton system as a function of treatment time. (c) Evolution of the UV-vis spectra of AO7 with treatment time. (d) Degradation kinetics of $\mathrm{AO} 7$ recorded over $24 \mathrm{~h}$ from a fresh solution at week 0 , week 1, week 4 and week 8 . Conditions: $90 \mathrm{~mL} \mathrm{AO7} \mathrm{(0.1} \mathrm{mM)} \mathrm{aqueous}$ solution in $50 \mathrm{mM} \mathrm{Na}_{2} \mathrm{SO}_{4}$ with $0.20 \mathrm{mM} \mathrm{Fe}^{2+}$ at $\mathrm{pH}$ 3.0. and short-chain carboxylic acids that deactivate the ${ }^{\circ} \mathrm{OH}$ radicals. Hence, the AO7 decomposition increases by only $\sim 20 \%$ in the seven following hours, resulting in about $90 \%$ elimination of $\mathrm{AO} 7$ after $10 \mathrm{~h}$ of the electro-catalytic process. On the other hand, the absorption peaks at 254 and $310 \mathrm{~nm}$ (spectrophotometry), attributed to aromatic amines and naphthalene in the initial mother solution, are also weakened as a result of the increased treatment time (elimination of the aromatic ring structure by ${ }^{\circ} \mathrm{OH}$ - Fig. 5c). In order to evaluate the durability of the studied FC-Fenton system, the decay kinetics of AO7 was monitored over two months. The cathodic compartment was weekly replenished with fresh $\mathrm{AO} 7(0.1 \mathrm{mM})$ solution with $\mathrm{Na}_{2} \mathrm{SO}_{4}$ and $0.20 \mathrm{mM} \mathrm{Fe}{ }^{2+}$ at $\mathrm{pH}=3$; while in the anodic compartment, the abiotic anode and the solution were kept unchanged. The breaking of the azo bond in the AO7 structure (Fig. 5a) by ${ }^{\circ} \mathrm{OH}$ was identified by measuring the absorbance of the solution at $\lambda=485 \mathrm{~nm}$. As a result of the high consistency of both gold nanoparticles and the pC layer at the anode and cathode electrodes, respectively, the cell current output remained stable during at least two months and led to a steady degradation of AO7 from water (Fig. 5d). From Fig. 4a, it could be clearly noticed that the ORR occurs at less negative potentials after modification of CF ( $-0.21 \mathrm{~V} v$ s. Ag/AgCl on CF@pC instead of $-0.67 \mathrm{~V}$ on bare $\mathrm{CF}$ ). This observation is of an utmost importance when applying such a cathode in the proposed FC-Fenton system. In fact, the glucose oxidation at the anode takes place at $-0.46 \mathrm{~V}$ vs. $\mathrm{Ag} / \mathrm{AgCl}$, which would make it impossible to employ a combination of the CF@Au anode and raw CF cathode in the experimental setup. These results prove the promising efficiency of the proposed FC-Fenton cell for the zero-energy depollution systems of acidic solutions and could be further extended to membrane-coupled reactor systems. This study is currently in progress and will be the subject of our next communication.

Compared with other studies from the literature, ${ }^{\mathbf{1 4 , 1 5 , 1 7}}$ the present FC-Fenton system shows remarkable advantages such as: (i) virtually zero energy costs (no need of any external power generator), (ii) simple and fast operating cell at ambient temperature with no need of an anaerobic medium (contrary to bacterial electrodes and biofilms), (iii) accelerated ORR leading to $\mathrm{H}_{2} \mathrm{O}_{2}$ production at higher potentials, (iv) low negative potentials leading to more efficient pollutants removal and finally, (v) long-term stability enabling multiple degradation cycles without decreasing the catalytic activity over time.

\section{Conclusions}

The present work demonstrates the potential of a smart ecofriendly approach for the removal of persistent organic pollutants (POPs) from water without using any external power input. The proposed green technology relies upon a FC-Fenton system composed of an originally designed porous CFs cathode and CF@Au anode placed in a cell with two-chambers separated by a protonic exchange membrane (Nafion). The original synthesis of the cathode electrode, based on ALD of $\mathrm{ZnO}$ and its subsequent solvothermal conversion to ZIF-8 and pyrolysis, produced a porous carbon material with beneficial electrocatalytic 
properties for the diffusion and the reduction of oxygen into $\mathrm{H}_{2} \mathrm{O}_{2}$. The presence of gold particles on the CFs anode allowed the direct electro-oxidation of glucose to supply green electrons for the ORR. The catalytic properties of both anode and cathode induce a stable output current density of $360.3 \pm 51.5 \mathrm{~mA} \mathrm{~m}^{-2}$ at $400 \pm 50 \mathrm{mV}$ that could be maintained for long period of time. As a consequence, $90 \%$ of the initial concentration of the azo dye pollutant AO7, identified by HPLC analysis, was eliminated upon extended EF degradation for $10 \mathrm{~h}$; and the cell power output of $170 \mathrm{~mW} \mathrm{~m}^{-2}$ was stable at least for two months. Hence, this first proof of concept of an abiotic FC-Fenton system demonstrates high efficiency towards pollutant degradation with a huge potential in both energy-related areas and environmental protection.

\section{Acknowledgements}

We gratefully acknowledge financial support from Vietnamese government (VIED - Vietnam International Education Development - Project 911) and the ANR project ECOTS/CELECTRON for the partial co-funding of this research.

\section{References}

1 H. C. Arredondo Valdez, G. Garcia Jimenez, S. Gutierrez Granados and C. Ponce de Leon, Degradation of paracetamol by advance oxidation processes using modified reticulated vitreous carbon electrodes with $\mathrm{TiO}(2)$ and $\mathrm{CuO} / \mathrm{TiO}(2) / \mathrm{Al}(2) \mathrm{O}(3)$, Chemosphere, 2012, 89(10), 11951201.

2 L. Thi Xuan Huong, B. Mikhael, C. Joffrey and C. Marc, A highly active based graphene cathode for the electroFenton reaction, RSC Adv., 2015, 5, 42536-42539.

3 A. Özcan, Y. Şahin, A. Savaş Koparal and M. A. Oturan, Carbon sponge as a new cathode material for the electroFenton process: comparison with carbon felt cathode and application to degradation of synthetic dye basic blue 3 in aqueous medium, J. Electroanal. Chem., 2008, 616(1-2), 7178.

4 G. Xia, Y. $\mathrm{Lu}$ and $\mathrm{H}$. Xu, Electrogeneration of hydrogen peroxide for electro-Fenton via oxygen reduction using polyacrylonitrile-based carbon fiber brush cathode, Electrochim. Acta, 2015, 158, 390-396.

5 L. Zhou, Z. Hu, C. Zhang, Z. Bi, T. Jin and M. Zhou, Electrogeneration of hydrogen peroxide for electro-Fenton system by oxygen reduction using chemically modified graphite felt cathode, Sep. Purif. Technol., 2013, 111, 131-136.

$6 \mathrm{X}$. Zhang, J. Fu, Y. Zhang and L. Lei, A nitrogen functionalized carbon nanotube cathode for highly efficient electrocatalytic generation of $\mathrm{H}_{2} \mathrm{O}_{2}$ in electroFenton system, Sep. Purif. Technol., 2008, 64(1), 116-123.

7 E. Pajootan, M. Arami and M. Rahimdokht, Discoloration of wastewater in a continuous electro-Fenton process using modified graphite electrode with multi-walled carbon nanotubes/surfactant, Sep. Purif. Technol., 2014, 130, 34-44.

8 G. Zhang, F. Yang, M. Gao, X. Fang and L. Liu, Electro-Fenton degradation of azo dye using polypyrrole/ anthraquinonedisulphonate composite film modified graphite cathode in acidic aqueous solutions, Electrochim. Acta, 2008, 53(16), 5155-5161.

9 T. X. H. Le, C. Charmette, M. Bechelany and M. Cretin, Facile Preparation of Porous Carbon Cathode to Eliminate Paracetamol in Aqueous Medium Using Electro-Fenton System, Electrochim. Acta, 2016, 188, 378-384.

10 T. X. H. Le, M. Bechelany, S. Lacour, N. Oturan, M. A. Oturan and M. Cretin, High removal efficiency of dye pollutants by electron-Fenton process using a graphene based cathode, Carbon, 2015, 94, 1003-1011.

$11 \mathrm{~A}$. Ozcan and M. Gencten, Investigation of acid red 88 oxidation in water by means of electro-Fenton method for water purification, Chemosphere, 2016, 146, 245-252.

12 S. Garcia-Segura, E. Brillas, L. Cornejo-Ponce and R. Salazar, Effect of the $\mathrm{Fe}^{3+} / \mathrm{Cu}^{2+}$ ratio on the removal of the recalcitrant oxalic and oxamic acids by electro-Fenton and solar photoelectro-Fenton, Sol. Energy, 2016, 124, 242-253.

13 M. A. Fernandez de Dios, A. G. del Campo, F. J. Fernandez, M. Rodrigo, M. Pazos and M. A. Sanroman, Bacterialfungal interactions enhance power generation in microbial fuel cells and drive dye decolourisation by an ex situ and in situ electro-Fenton process, Bioresour. Technol., 2013, 148, 39-46.

14 L. Zhang, X. Yin and S. F. Y. Li, Bio-electrochemical degradation of paracetamol in a microbial fuel cell-Fenton system, Chem. Eng. J., 2015, 276, 185-192.

15 X. W. Liu, X. F. Sun, D. B. Li, W. W. Li, Y. X. Huang, G. P. Sheng, et al., Anodic Fenton process assisted by a microbial fuel cell for enhanced degradation of organic pollutants, Water Res., 2012, 46(14), 4371-4378.

$16 \mathrm{X}$. Zhu and B. E. Logan, Using single-chamber microbial fuel cells as renewable power sources of electro-Fenton reactors for organic pollutant treatment, J. Hazard. Mater., 2013, 252-253, 198-203.

17 C.-H. Feng, F.-B. Li, H.-J. Mai and X.-Z. Li, Bio-Electro-Fenton Process Driven by Microbial Fuel Cell for Wastewater Treatment, Environ. Sci. Technol., 2010, 44(5), 1875-1880.

18 Y. Gong, C. Zhang, Q. Yan, W. He, W. Xiao, J. Lin, et al., Enhanced enzymatic hydrolysis of sugarcane bagasse hemicellulose using recombinant glucose oxidase expressed by Pichia pastoris, Ind. Crops Prod., 2015, 77, 458-466.

19 M. G. Hosseini and I. Ahadzadeh, Electrochemical impedance study on methyl orange and methyl red as power enhancing electron mediators in glucose fed microbial fuel cell, J. Taiwan Inst. Chem. Eng., 2013, 44(4), 617-621.

20 C.-C. Chen, C.-L. Lin and L.-C. Chen, Functionalized Carbon Nanomaterial Supported Palladium Nano-Catalysts for Electrocatalytic Glucose Oxidation Reaction, Electrochim. Acta, 2015, 152, 408-416.

21 A. M. Ghonim, B. E. El-Anadouli and M. M. Saleh, Electrocatalytic glucose oxidation on electrochemically oxidized glassy carbon modified with nickel oxide nanoparticles, Electrochim. Acta, 2013, 114, 713-719. 
22 J.-S. Ye, Z.-T. Liu, C.-C. Lai, C.-T. Lo and C.-L. Lee, Diameter effect of electrospun carbon fiber support for the catalysis of Pt nanoparticles in glucose oxidation, Chem. Eng. J., 2016, 283, 304-312.

23 C.-T. Hsieh, Y.-F. Chen and P.-Y. Yu, Deposition of binary Pd-Rh catalysts on nanostructured carbon supports for non-enzymatic glucose oxidation, Int. J. Hydrogen Energy, 2015, 40(43), 14857-14865.

24 D. Basu and S. Basu, A study on direct glucose and fructose alkaline fuel cell, Electrochim. Acta, 2010, 55(20), 5775-5779.

25 K. W. Jung, D. S. Park, M. J. Hwang and K. H. Ahn, Decolorization of acid orange 7 by an electric field-assisted modified orifice plate hydrodynamic cavitation system: optimization of operational parameters, Ultrason. Sonochem., 2015, 26, 22-29.

26 T. X. Huong Le, M. Bechelany, A. Both Engel, M. Cretin and S. Tingry, Growth of gold particles on carbon felt for efficient micropower generation in a hybrid biofuel cell, Electrochim. Acta, 2016, submitted.

27 A. Abou Chaaya, R. Viter, I. Baleviciute, M. Bechelany, A. Ramanavicius, Z. Gertnere, et al., Tuning Optical Properties of $\mathrm{Al}_{2} \mathrm{O}_{3} / \mathrm{ZnO}$ Nanolaminates Synthesized by Atomic Layer Deposition, J. Phys. Chem. C, 2014, 118(7), 3811-3819.

28 A. Abou Chaaya, R. Viter, M. Bechelany, Z. Alute, D. Erts, A. Zalesskaya, et al., Evolution of microstructure and related optical properties of $\mathrm{ZnO}$ grown by atomic layer deposition, Beilstein J. Nanotechnol., 2013, 4, 690-698.

29 A. J. Bard and L. R. Faulkner, Electrochemical Methods: Fundamentals and Applications, John Wiley and Sons, New York, 2000.

30 M. Wen, H. Liu, F. Zhang, Y. Zhu, D. Liu, Y. Tian, et al., Amorphous FeNiPt nanoparticles with tunable length for electrocatalysis and electrochemical determination of thiols, Chem. Commun., 2009, (30), 4530-4532.

31 R. P. Ramasamy and S. M. Maliyekkal, Formation of gold nanoparticles upon chitosan leading to formation and collapse of gels, New J. Chem., 2014, 38(1), 63-69.

$32 \mathrm{H}$. Weimin and J. Shi, Synthesis and Properties of $\mathrm{ZrO}_{2}$ Films Dispersed With Au Nanoparticles, J. Sol-Gel Sci. Technol., 2001, 20, 145-151.

33 S. B. Aoun, Electrocatalytic Oxidation of Glucose at Gold Nanoparticle-modified PFC electrodes in an Alkaline Solution, J. Mater. Environ. Sci., 2013, 4(6), 887-892.
34 M. Pasta, F. La Mantia and Y. Cui, Mechanism of glucose electrochemical oxidation on gold surface, Electrochim. Acta, 2010, 55(20), 5561-5568.

35 C. Paul Wilde and M. Zhang, Oxidation of Glucose at Electrodeposited Platinum Electrodes in Alkaline Solution, J. Chem. Soc., Faraday Trans. 1, 1993, 89(2), 385-389.

36 X. Yan, X. Ge and S. Cui, Pt-Decorated nanoporous gold for glucose electrooxidation in neutral andalkaline solutions, Nanoscale Res. Lett., 2011, 6, 313.

37 M. Pasta, R. R. Ruffo, E. Falletta, C. M. Mari and C. D. Pina, Alkaline glucose oxidation on nanostructured gold electrodes, Gold Bull., 2010, 43, 57-64.

38 C. Adib Abou, B. Mikhael, B. Sebastien and P. Miele, ZnO 1D nanostructures designed by combining atomic layer deposition and electrospinning for UV sensor applications, J. Mater. Chem. A, 2014, 2, 20650.

39 M. Jiang, X. Cao, D. Zhu, Y. Duan and J. Zhang, Hierarchically Porous N-doped Carbon Derived from ZIF-8 Nanocomposites for Electrochemical Applications, Electrochim. Acta, 2016, 196, 699-707.

40 X. Ma, L. Li, S. Wang, M. Lu, H. Li, W. Ma, et al., Ammoniatreated porous carbon derived from ZIF-8 for enhanced $\mathrm{CO}_{2}$ adsorption, Appl. Surf. Sci., 2016, 369, 390-397.

41 L. Zhou, M. Zhou, Z. Hu, Z. Bi and K. G. Serrano, Chemically modified graphite felt as an efficient cathode in electroFenton for $p$-nitrophenol degradation, Electrochim. Acta, 2014, 140, 376-383.

42 N. Alexeyeva, E. Shulga, V. Kisand, I. Kink and K. Tammeveski, Electroreduction of oxygen on nitrogendoped carbon nanotube modified glassy carbon electrodes in acid and alkaline solutions, J. Electroanal. Chem., 2010, 648(2), 169-175.

43 Y. Liu, S. Chen, X. Quan, H. Yu, H. Zhao and Y. Zhang, Efficient Mineralization of Perfluorooctanoate by ElectroFenton with $\mathrm{H}_{2} \mathrm{O}_{2}$ Electro-generated on Hierarchically Porous Carbon, Environ. Sci. Technol., 2015, 49(22), 1352813533.

44 W. Ren, Q. Peng, H. Za, Z. Zhang, W. Zhan, K. Lv, et al., Effect of Pore Structure on the Electro-Fenton Activity of ACF@OMC Cathode, Ind. Eng. Chem. Res., 2015, 54(34), 8492-8499.

45 L. Zhang, Z. Su, F. Jiang, L. Yang, J. Qian, Y. Zhou, et al., Highly graphitized nitrogen-doped porous carbon nanopolyhedra derived from ZIF-8 nanocrystals as efficient electrocatalysts for oxygen reduction reactions, Nanoscale, 2014, 6(12), 6590-6602. 